\title{
KEBIJAKAN PENDIDIKAN KOSMOPOLITAN MUHAMMADIYAH DI TENGAH TANTANGAN ERA DISRUPSI
}

\author{
Sony Bakhtiar \\ SMA Muhammadiyah 3 Jember, Jember, Indonesia \\ sonybakhtiar@yahoo.com
}

\begin{abstract}
Abstrak
Saat ini, di era disrupsi kemajuan teknologi informasi mulai menggantikan peran manusia dalam beberapa bidang pekerjaan.Keadaan ini akan meningkatkan jumlah pengangguran apabila tidak dilakukan antisipasi. SMA Muhammadiyah 3 Jember berupaya memberikan perhatian yang seimbang antara program intrakurikuler dan ekstrakurikuler. Kegiatan ekstrakulikuler dapat mengasah potensi minat dan bakat siswa. Ekstrakulikuler memberikan nilai tambah berupa cara pikir saintik, kreatif, dan inovatif. Hal tersebut sebagai inti edupreneurship di SMA dalam menghadapi era disrupsi. Penerapan edupreneurship membutuhkan komitmen kepala sekolah dan guru. Penelitian ini bertujuan mengetahui penerapan edupreneurship dalam kegiatan intrakurikuler dan ekstrakurikuler selama 2016-2018 di SMA Muhammadiyah 3 Jember. Metode penelitian ini adalah metode deskriptif campuran dengan teknik pengumpulan data melalui wawancara, pengamatan langsung di lapangan serta studi literatur. Hasil penelitian ini menunjukkan bahwa beberapa guru dan siswa mampu menghasilkan karya orijinal, kreatif dan inovatif berbasis masalah melalui intrakurikuler dan ekstrakurikuler. Siswa juga lebih mengerti oleh guru yang mampu menghubungkan teori dengan mata pelajaran melalui sumber ajaran Islam dan nilai kemanusiaan.
\end{abstract}

Kata kunci : Disrupsi, pendidikan berkemajuan, edupreneurship, inovatif

\begin{abstract}
At present, in the era of disruption of advances in information technology began to replace the role of humans in several fields of work.This situation will increase the number of unemployed if there is no anticipation.Senior High School Jember Muhammadiyahseeks to provide balanced attention between intracurricular and extracurricular programs. Extracurricular activities can hone the potential of students' interests and talents. Extracurricular provides added value in the form of scientific, creative and innovative thinking. This is the core of edupreneurship in high school in the face of the era of disruption. The application of edupreneurship requires the commitment of the principal and the teacher. This study aims to determine the application of edupreneurship in intracurricular and extracurricular activities during 2016-2018 at Muhammadiyah 3 Jember High School. The method of this research is a mixed descriptive method with data collection techniques through interviews, direct observation in the field and literature studies. The results of this study indicate that some teachers and students are able to produce original, creative and innovative work based problems through intracurricular and extracurricular. Students also understand more by teachers who are able to connect theory with subjects through sources of Islamic teachings and human values.
\end{abstract}

Keywords : Disruption, progressive education, edupreneurship, innovative

Submited: 19-02-2019; Accepted: 29-04-2019; Published: 30-04-2019

*Korespondensi: SMA Muhammadiyah 3 Jember, Indonesia

Jl. Mastrip No. 3, Lingkungan Panji, Tegalgede, Sumbersari, Jember, Jawa Timur, 68124

Email: sonybakhtiar@yahoo.com 


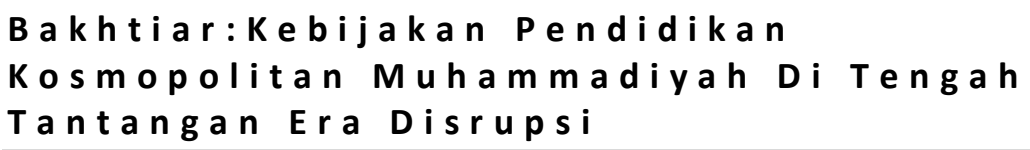

\section{PENDAHULUAN}

Era modern saat ini yang mana hampir sebagaian sektor menggunakan teknologi modern, ketika saat ini sudah mulai menerapakan revolusi industri 4.0 yang mana setiap kegiatan menggunakan teknologi digital dan memudahkan manusia dalam bekerja disetiap kegiatan nya(Melinda 2018). Sehubung dengan gemparnya revolusi industri 4.0 bidang pendidikan yang di baawahi oleh naungan Muhammadiyah mulai ingin menerapkan kosep-konsep yang dianggap dapat memajukan pendidikan baik kemajuan dari segi siswa dan segi kualitas pengajar itu sendiri.

Muhammadiyah merupakan suatu organisasi berbasis Islam yang ikut andil dalam dunia pendidikan, setiap organisasi memiliki ciri khas nya sendiri dalam mengolah dan mengatur setiap bagian yang ditempatinya. Identitas kekhasan ini tentu saja dibalut oleh baju yang bernama ideology. Di dalam bidang pendidikan, Muhammadiyah terkenal dengan konsep keislaman nya. Tetapi, kali ini pendidikan di Muhammadiyah menggunakan konsep yang berbeda.

Konsep pendidikan (Warsono 2017) tersebut yaitu konsep pendidikan kosmopolitan (Nuryanto 2017). Muhammadiyah menawarakan pendidikan Islam yang universal, terbuka, toleran, dan memiliki kepedulian terhadap kemanusiaan. Dengan menggunakan konsep ini yang mana konsep ini juga mendorong untuk memiliki sikap yang kritis terhadap kondisi sekitar serta mampu membaca dan merespon segala bentuk tantangan di masa kini dan masa yang akan datang.

Marcus pun berpendapat bahwa dengan menerapkan nilai-nilai dari kosmopolitanisme yang merupakan nilai-nilai sosial akan mempermudah dalam menyelesaikan masalah-masalah yang ada dimana ketika tiap-tiap individu ini menghormati yang satu dengan yang lainnya, maka perdamaian akan lebih mudah untuk diraih (Nussbaum 2006).

Saat ini kebutuhan akan kecepatan dan efisiensi di segala bidang telah mendorong manusia untuk menciptakan inovasi baru. Tanpa terasa revolusi industri 3.0 telah mulai bergeser dan saat ini kita semua sedang memasuki era revolusi industri 4.0. Sebuah era yang menuntut kita untuk melakukan evolusi gaya hidup dari era penggunaan peralatan dan mesin sederhana menuju era penggunaan media berteknologi informasi dan komunikasi yang lebih 
memudahkan manusia dalam melakukan kegiatan sehingga tenaga manusia kurang dipakai lagi.

Seperti Artificial intelligence berbentuk robot serta software apikasi komputer sebagai produk teknologi informasi dan komunikasi secara cepat dan masif mulai mengganggu eksistensi manusia di berbagai bidang. Gangguan yang lebih dikenal dengan istilah disruptive technology atau disruptive innovation ini sedikit banyak telah berkontribusi terhadap bertambahnya jumlah pengangguran di Indonesia.

Jumlah pengangguran ini meningkat sebab tenaga mereka dikalahkan oleh mesin sebab revolusi industry 4.0 itu sendiri. Pemerintah telah melakukan beberapa kebijakan pembangunan dengan maksimal untuk mengurangi jumlah penduduk miskin, meningkatkan pendidikan juga ditemukan menjadi faktor kunci pengentasan kemiskinan (Gokan 2011), tetapi sampai sekarang masih ada pengangguran. Jika tidak segera diambil langkah antisipasi maka tingkat pengangguran yang tinggi akan menimbulkan multiplayer effect di berbagai bidang. Menurut Sadono Sukirno (Sukirno 2006), semakin turunya tingkat kemakmuran akan menimbulkan masalah kemiskinan.

Hilangnya berbagai bidang pekerjaan sebagai akibat hadirnya gangguan inovasi baru telah membuka peluang hadirnya jenis pekerjaan baru. Sebuah peluang yang hanya dapat diambil dan dimanfaatkan bagi mereka yang memiliki karakter kuat serta memiliki kreativitas tinggi untuk mampu menciptakan sebuah inovasi baru lainnya.

Tantangan kedepanyang harus dijawab oleh institusi pendidikan beserta seluruh stakeholder-nya sebagai ujung tombak pencetak sumberdaya manusia unggul dan berdaya saing tinggi. Sebagai salah satu pemangku kepentingan di bidang pendidikan, guru memiliki peran penting dalam mewujudkannya. Selain itu, baik dari pengajar dan siswa harus pandai berkolaborasi dalam menciptakan suatu karya yang menakjubkan.

Muhammadiyah sebagai organisasi Islam yang memiliki amal usaha pendidikan yang mana di Indonesia cukup besar dan terkenal. Tentunya menyadari pentingnya mempersiapkan strategi agar amal usaha pendidikan yang dimilikinya mampu menjawab tantangan di masa kini dan yang akan datang. Untuk mewujudkan hal tersebut tentu bukan hal yang mudah. Butuh usaha dan keinginan yang kuat agar semua rencana tercapai. 


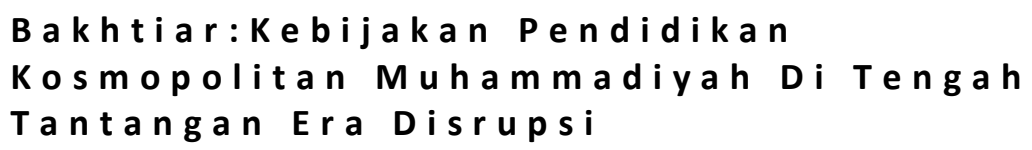

Untuk mewujudkan hal-hal tersebut dibutuhkan nya usaha dari pihak Muhammadiyah itu sendiri dan sumberdaya yang dimiliki oleh amal usaha pendidikan harus memiliki sifat yang adaptable dan tidak alergi terhadap perubahan. Permasalahan yang ada harus segera dijawab dengan sebuah inovasi agar mampu menjawab tantangan di era disrupsi. Dari segi pendidikan, pengajar yang dipakai oleh pihak Muhammadiyah sendiri haruslah tidak buta teknologi yang sedang berkembang di era ini.

Salah satu tantangan yang ada adalah pengelolaan pembelajaran di sekolah yang lebih berorientasi pada ujian nasional sehingga mendorong guru dan siswa untuk fokus pada pencapaian target ketuntasan materi pelajaran sesuai standar kompetensi lulusan. Apabila guru tidak memiliki kompetensi profesional, sosial, dan pedagogis yang mumpuni, proses pembelajaran yang seharusnya memberikan pengalaman belajar yang bermakna akan terabaikan. Proses pembelajaran menjadi membosankan karena guru tidak lagi mampu menjadi agent of changeakan tetapihanya berperan sebagai pentransfer materi pelajaran. Tidak heran jika sebagian siswa menganggap sekolah bukan sebagai tempat menyenangkan untuk belajar melainkan sebagai tempat yang lebih mirip sebagai 'penjara' pemasung kebebasan dan kreativitas. Jika hal ini tidak segera disadari maka bakat dan minat siswa yang sebenarnya akan kesulitan menemukan tempat untuk beraktualisasi. Sebab siswa merasa dirinya berada di dalam ruang yang memiliki batasan.

Amal usaha pendidikan Muhammadiyah yang memiliki misi pendidikan (Karsidi 2017) berkemajuan serta mencerahkan sudah harus memikirkan strategi terbaik guna meraih target sukses Ujian Nasional dari kurikulum sekaligus mendorong guru dan siswa untuk mulai membiasakan diri untuk mengasah High Order Thinking Skill (HOTS). Penerapan edupreneurship di sekolah menengah umum merupakan salah satu jawaban yang akan memberikan manfaat baik kepada siswa, guru maupun sekolah.

Edupreneurship akan mendorong guru dan siswa untuk memiliki keterampilan berpikir kritis dengan cara yang kreatif, inovatif, dan menyenangkan melalui pemanfaatan teknologi informasi dan komunikasi. Di sisi lain, melalui penerapan edupreneurship guru dan siswa diharapkan akan terlatih sensitivitasnya apabila melihat sebuah permasalahan masyarakat dan mampu merumuskan masalah serta mencari jalan keluar dengan ilmu pengetahuan yang dipelajari di 
sekolah dan pada akhirnya dapat mendorong terciptanya inovasi baru hasil kreasi guru dan siswa.

Sebagai penyempurna agar pembelajaran mampu memberikan nilai tambah dari segi akidah dan akhlak, guru juga diharapkan mampu mengaitkan materi pembelajaran dengan sumber ajaran Islam dan nilai kemanusiaan sehingga siswa dapat memperoleh dua manfaat sekaligus yaitu bertambahnya ilmu pengetahuan umum dan bertambahnya aqidah dan akhlak melalui pemahaman ayat-ayat kauniyah dalam materi pembelajaran.

SMA Muhammadiyah 3 Jember masih menemui kendala dalam menyajikan proses pembelajaran yang kreatif, inovatif, dan menyenangkan dalam keseluruhan kegiatan intrakurikuler. Namun, kerjasama bidang kesiswaan dengan beberapa guru sejak tahun 2016 hingga kini mencoba untuk melakukan terobosan dengan mempertinggi dan memfasilitasi seluruh ekstrakurikuler khususnya kegiatan ekstrakurikuler yang mampu melatih siswa yang terampil memanfaatkan teknologi informasi dan komunikasi, berpikir kritis sekaligus kreatif hingga mampu mendorong lahirnya guru dan siswa yang kreatif dan inovatif sesuai minat dan bakatnya serta mampu menghasilkan karya inovasi baru sebagai bekal menghadapi tantangan era disruptive innovation.

Melalui cara memfasilitasi dan meningkatkan kualitas ekstrakulikuler ini para siswa tidak merasa terpenjara saat melakukan kegiatan di sekolah. Dengan ini para guru serta pihak yayasan berharap para siswa dapat memberikan timbal balik yang baik untuk pihak sekolah sendiri.

\section{METODE PENELITIAN}

Pendekatan penelitian yang digunakan dalam pendidikan cosmopolitan Muhammadiyah di tengah tantangan era disrupsi adalah menggunakan metode campuran (Mixed Method Research) yaitu dengan menggabungkan pendekatan kualitatif dengan pendekatan kuantitatif. Menurut Creswell (Creswell 2014), metode penelitian campuran merupakan pendekatan penelitian dengan mengkombinaskan antara penelitian kualitaif dengan peneitian kuantitatif. Pendekatan kualitatif merupakan sebuah proses penyelidikan untuk memahami masalah sosial atau masalah manusia berdasarkan pada penciptaan gambaran holistik lengkap yang dibentuk dengan kata-kata, melaporkan pandangan informan secara terperinci dan disusun dalam sebuah latar belakang alamiah 


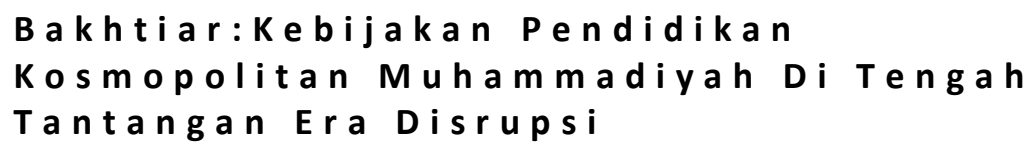

(Cresswell 2002). Penelitian kualitatif dilakukan untuk menemukan gambaran yang menyeluruh dan mendalam tentang obyek yang diteliti, dengan berangkat dari suatu fenomena yang ada, penelitian ini juga tidak berangkat dari suatu teori yang hendak diuji kebenarannya (Alwasilah 2003). Analisis secara kualitaif menggunakan triangulasi sumber berdasarkan komentar dan saran yang diberikan ahli (expert judgement) dan hasil wawancara. Teknik analisis data dianalisis secara deskriptif lalu disajikan dalam bentuk naratif. Lokasi penelitian berlangsung di SMA Muhammadiyah 3 Jember. Penentuan jumlah informan sesuai dengan kebutuhan yakni siswa dan guru yang mewakili kegiatan pembelajaran intrakurikuler dan ekstrakurikuler. Teknik pengumpulan data melalui pengamatan langsung di lapangan, wawancara, serta studi literatur.

Penelitian yang relevan dengan judul yang diangkat oleh peneliti adalah :Penelitian yang dilakukan oleh Ali, Kuntoro, Sutrisno pada tahun 2016 dengan judul "Pendidikan berkemajuan : Refleksi Praksis Pendidikan KH. Ahmad Dahlan”. Tujuan dari artikel ilmiah ini adalah: (1) fondasi, dimensi, dan filsafat dan teori pendidikan berkemajuan K.H. Ahmad Dahlan (1868-1923), dan (2) merefleksikan praksis pendidikan K.H. AhmadDahlan untuk menyusun bagan konseptual pendidikan berkemajuan. Penelitian sejarah dapat dilihat dari segi prespektif sejarah atau historis, serta waktu terjadinya fenomena-fenomena yang diselidiki (Usman, 1986). Penelitian ini menggunakan metode sejarah yang mencakup empat tahapan: heuristik, kritik, interpretasi, dan historiografi. Mengaplikasikan analisis historis pendekatan situasional Berkhofer Jr. Penelitian berhasil menemukan bahwa: (1) fondasi pendidikan berkemajuan adalah agama yang berdialektika dengan kehidupan sosial; tiga dimensi pendidikan berkemajuan mencakup penghargaan atas akal (kecerdasan), berorientasi pada pengamalan (experience), dan menggerakkan kemajuan sosial (progress); filsafat dan teori pendidikan K.H. Ahmad Dahlan bercorak progresif relijius yang mendorong kemajuan hidup duniawi dan kemuliaan hidup akhirat. (2) Secara konseptual pendidikan berkemajuan berlandaskan agama dan kehidupan sosial yang sangat menghargai kecerdasan (akal/intelijensia) sebagai piranti untuk memahami pesanpesan agama dan anatomi kehidupan sosial, dan bertujuan untuk menumbuhkan akal (kecerdasan) sehingga bertumbuh (growth) utuh kepribadiannya dan bersedia terlibat dalam menggerakkan kemajuan sosial (progress). 
Makalah Pengembangan Edupreneurship Sekolah Kejuruan, Mulyatiningsih, Sugiyono dan Purwanti pada tahun 2014 menjelaskan tentang penerapan konsep edupreneurship di sekolah menengah kejuruan. Meskipun obyek dalam makalah ini adalah sekolah kejuruan namun konsep dasar dari edupreneurship masih relevan diterapkan pada sekolah menengah umum. Materi yang dibahas dalam makalah tersebut antara lain konsep edupreneurship, pengembangan potensi edupreneurship, manajemen edupreneurship, peran kerjasama dalam edupreneurship, dan best practices.

Berdasarkan Undang-Undang Dasar hasil amandemen pasal 31 ayat 3 menyatakan "Pemerintah mengusahakan dan menyelenggarakan satu system pendidikan nasional, meningkatkan keimanan dan ketakwaan serta akhlak mulia dalam rangka mencerdaskan kehidupan bangsa yang diatur dengan undangundang". Hal ini diperkuat dalam pasal 31 ayat 5, "Pemerintah memajukan ilmu pengetahuan dan teknologi dengan menjunjung tinggi nilai-nilai agama dan persatuan bangsa untuk kemajuan peradaban serta kesejahteraan umat manusia”.

Demikian pula dituturkan dalam Undang-Undang No.20 tahun 2003 tentang sistem pendidikan nasional pasal 3 berbunyi "Tujuan pendidikan nasional adalah mengembangkan potensi peserta didik agar menjadi manusia yang beriman dan bertakwa kepada Tuhan Yang Maha Esa, berakhlak mulia, sehat, berilmu, cakap, kreatif, mandiri, dan menjadi warga negara yang demokratis serta bertanggung jawab".

Semangat dan tanggung jawab pemerintah di bidang pendidikan yang tertuang dalam Undang-Undang Dasar hasil amandemen pasal 31 ayat 3 dan ayat 5 serta pemaparan tujuan pendidikan nasional pada Undang-Undang No. 20 tahun 2003 diatas sejalan dengan nafas pendidikan Muhammadiyah yang holistik dan mencerahkan. Hasil kajian yang lebih komprehensif tentang hal tersebut ditulis oleh

Mohamad Ali, Sodiq Azis Kuntoro, Sutrisno Sutrisno 2016 "Pendidikan berkemajuan : Refleksi Praksis Pendidikan KH. Ahmad Dahlan". Dalam penelitian ilmiahnya tersebut dirumuskan bahwa praksis pendidikan berkemajuan adalah bahwa fondasi pendidikan berkemajuan merupakan agama yang berdialektika dengan kehidupan sosial yang mencakup mencakup penghargaan atas akal (kecerdasan), berorientasi pada pengamalan (experience), dan menggerakkan kemajuan sosial (progress). Sedangkan secara konseptual 
Bakhtiar:Kebijakan Pendidikan

Kosmopolitan Muhammadiyah Di Tengah

Tantangan Era Disrupsi

pendidikan berkemajuan berlandaskan agama dan kehidupan sosial yang sangat menghargai kecerdasan / akal sebagai piranti untuk memahami pesan-pesan agama dan anatomi kehidupan sosial, dan bertujuan untuk menumbuhkan akal (kecerdasan) sehingga bertumbuh (growth) utuh kepribadiannya dan bersedia terlibat dalam menggerakkan kemajuan sosial (M. Ali, S. A. Kuntoro 2016).

Kecerdasan manusia yang berlandaskan nilai-nilai agama akan menghasilkan berbagai inovasi yang bermanfaat bagi kemanusiaan. Pada era teknologi informasi dan komunikasi (TIK), manusia semakin dituntut untuk memanfaatkan segala bentuk perangkat teknologi informasi dan komunikasi di berbagai bidang kehidupan. Dalam konteks pembelajaran,penggunaan komputer memang ditekankan, akan tetapi TIK bukan berarti terbatas pada penggunaan alatalat elektronik yang canggih (sophisticated), seperti pemanfaatan komputer dan internet, melainkan juga mencakup alat-alat yang konvensional, seperti: bahan tercetak, kaset audio, Overhead Transparancy (OHT)/Overhead Projector (OHP), bingkai suara (sound slides), radio, dan Televisi. TIK adalah semua teknologi yang berhubungan dengan pengambilan, pengumpulan (akuisisi), pengolahan, penyimpanan, penyebaran, dan penyajian informasi. TIK dalam pembelajaran dapat di bagi atas dua peran, yaitu: (1) sebagai media presentasi pembelajaran, misal berbentuk slide power point dan animasi dengan program flash; (2) sebagai media pembelajaran mandiri atau E-Learning yang dapat mendorong peserta didik untuk melakukan analisis dan sintesis pengetahuan, menggali, mengolah dan memanfaatkan informasi, menghasilkan tulisan, informasi dan pengetahuan sendiri. Jika dirancang dengan benar maka produk TIK akan menjadi alat bantu pembelajaran dalam rangka meningkatkan kualitas pembelajaran baik dari segi proses maupun hasilnya (C. Ismaniati 2012). Kendati demikian, sebagai sebuah alat dan media pembelajaran, peran TIK tidak akan memiliki dampak signifikan terhadap proses dan hasil pembelajaran apabila tidak berbanding lurus dengan peningkatan wawasan keilmuan dan keterampilan seorang guru dalam mengoperasikannya. Oleh sebab itu guru akan selalu ditantang untuk meningkatkan kompetensi pedagogik, sosial, dan profesional agar mampu mengemas sebuah proses pembelajaran yang sesuai dengan amanat Permendikbud No.22 tahun 2016 yaitu interaktif, inspiratif, menyenangkan, menantang, dan memotivasi peserta didik untuk berpartisipasi aktif, serta memberikan ruang yang 


\section{Ihe Journal of Society and Media 3(1)}

cukup bagi prakarsa, kreativitas, dan kemandirian sesuai dengan bakat, minat, perkembangan fisik serta psikologis peserta didik.

Seiring perkembangan zaman, pemerintah saat ini telah membuka pintu bagi masuknya institusi pendidikan asing di Indonesia. Sekolah negeri dan terlebih sekolah swasta wajib melakukan perbaikan kualitas pembelajarannya agar tetap mampu bersaing dan mendapatkan kepercayaan masyarakat. Menurut Oxford Project pada makalah Pengembangan Edupreneurship Sekolah Kejuruan yang disusun oleh Dr. Endang Mulyatiningsih,Perubahan setiap detik membutuhkan respon yang cepat pula dari para pendidik dan pengelola institusi pendidikan untuk bergerak cepat melakukan inovasi yang bermakna secara sistemik, perubahan transformasional, tanpa memperhatikan sumber daya yang ada, kapasitas saat ini atau tekanan nasional dalam rangka menciptakan kesempatan pendidikan baru dan keunggulan (Project 2012). Konsep edupreneurship dalam buku ini ditekankan pada usaha kreatif atau inovatif yang dilakukan oleh sekolah untuk memperoleh prestasi sekaligus menambah pemasukan sekolah.

Prestasi sekolah mungkin tidak langsung membuahkan keuntungan finansial tetapi sekolah yang berprestasi memiliki lebih banyak kesempatan untuk mendapat penghargaan, bantuan, dan inputsiswa yang lebih baik. Dengan modal prestasi ini, sekolah sedikit demi sedikit akan mengalami kemajuan sampai menjadi sekolah unggul. Dalam konteks ini, unggul tidak memberi dampak finansial secara langsung tetapi merintis masa depan yang lebih sukses dan membuat sekolah tersebut menjadi sekolah yang bonavit dikalangan masyarakat. Setelah menjadi sekolah unggul, peluang dan kesempatan untuk mencari tambahan income semakin mudah didapatkan.

Ketika pendapatan mudah didapat sebab ketenaran nama sekolah tersebut yang disebabkan oleh prestasi-prestasi yang diraih oleh para siswa membuat pandangan masyarakat terhadap sekolah tersebut menjadi baik bahkan membuat mereka tergiur untuk memasukan anaknya ke sekolah tersebut. semua sebab kolaborasi antara pengajar dan murid, terlebih tenaga pendidik yang professional dibidangnya.

Entrepreneurship di bidang sosial disebut sociopreneurship, di bidang edukasi disebut edupreneurship, di internal perusahaan disebut interpreneurship, di bidang bisnis teknologi disebut technopreneurship (Alim 2010). Oxford Project, (Project 2012) menjelaskan edupreneurship adalah sekolah- sekolah yang 


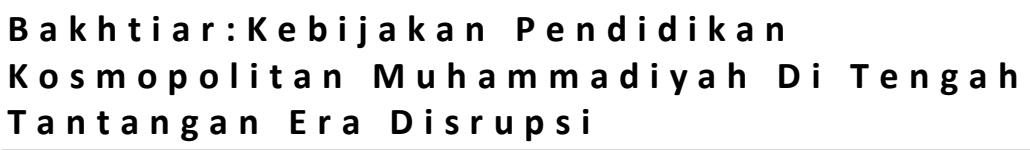

selalu melakukan inovasi yang bermakna secara sistemik, perubahan transformasional, tanpa memperhatikan sumber daya yang ada, kapasitas saat ini atau tekanan nasional dalam rangka menciptakan kesempatan pendidikan baru dan keunggulan.

Hal yang perlu dipersiapkan dalam penerapan edupreneurship adalah pertama, guru yang memiliki jiwa teacherpreneur yakni guru yang unggul dalam proses belajar mengajar, tanpa mengenal lelah dan tanpa pamrih mendidik para siswanya untuk menjadi seorang yang kreatif dan kompetitif dalam era global. Teacherpreneurs adalah individu yang berusaha untuk meningkatkan kualitas pendidikan melalui kegiatan berikut: (a) innovation, (b) leadership; (c) publishing; (d) policy; (e) research dan (f) entrepreneurship(Anon 2014). Peluang usaha seorang guru yang berjiwa teacherpreneur tentunya tidak terlepas dari konteks pendidikan, antara lain: (1) menjadi penulis tidak tetap dari berbagai media publikasi; (2) berinteraksi dengan pasar global untuk menjual kecerdasan dan idenya sebagai ahli pendidikan dan peneliti; (3) pengembang produk pendidikan kreatif seperti media, buku, modul, alat laboratorium dan perangkat pembelajaran; (4) mengembangkan bakat pedagogis, menjual keahliannya dengan menjadi narasumber atau tenaga ahli di mana-mana; dan (5) menjadi inovator untuk menyelesaikan masalah yang dihadapi peserta $\operatorname{didik}(E$. Mulyatiningsih, Sugiyono 2014).Kedua,adalah kurikulum sekolah yang harus fleksibel, menyeimbangkan antara standar isi dan proses, serta berfokus pada mempersiapkan peserta didik untuk memberikan keterampilan dan pengetahuan yang dibutuhkan lulusan untuk berhasil di pasar global. Peserta didik dilatih untuk belajar pentingnya konteks, pengambilan keputusan, berpikir kritis, berkolaborasi, dan apa artinya menjadi warga dunia yang memiliki koneksi tanpa batas. Ketiga, pengembangan model pembelajaran yang kreastif, inovatif dan menyenangkan, Keempat, Pemberdayaan Komite Sekolah dalam mendukung program sekolah, dan kelima, pemberdayaan siswa melalui pembelajaran maupun kegiatan lain berbasis proyek yang berujung pada dihasilkannya karya-karya kreatif dan inovatif siswa yang tidak hanya memiliki nilai tambah dalam aspek kognitif dan psikomotorik siswa namun lebih dari itu diharapkan semakin matangnya aspek afektif siswa terhadap setiap proses pembelajaran yang dilaluinya. Kesuksesan hidup lulusan akan terlihat dari kemampuannya beradaptasi pada setiap perubahan, termasuk disrupsi di dunia 
kerja akibat semakin majunya perkembangan Teknologi Informasi dan Komunikasi.

\section{HASIL DAN PEMBAHASAN}

Hasil observasi maupun wawancara dengan 15 orang yang terdiri dari siswa kelas XII IPA, XI IPS, dan XI Bahasa menunjukkan bahwa sekitar 90\% dari total 48 guru sering memasukkan pesan-pesan agama dalam pembelajaran namun hanya $10 \%$ saja yang mampu menghubungkan tema pembelajaran dengan konteks nilai-nilai ajaran Islam dan atau kemanusiaan. Terkait dengan praktik pendekatan saintifik yang kreatif, inovatif, dan menyenangkan belum semua guru mampu mengaplikasikan sesuai dengan konsep yang tertulis di RPP karena beberapa kendala, antara lain kepadatan jam mengajar, kesibukan kegiatan di luar sekolah, dan orientasi target penyelesaian materi serta target sukses Ujian Nasional bagi guru mata pelajaran Ujian Nasional.

Namun demikian, masih ada beberapa guru yang mampu meluangkan waktu lebih guna menghadirkan proses pembelajaran dengan konsep edupreneurship. Diantara guru-guru tersebut terdapat guru Kewarganegaraan yang mengajak siswa untuk observasi ke beberapa lembaga penegak hukum dan guru seni budaya berkolaborasi dengan ekstra teater melalui karya teater. Sedangkan guru Ekonomi memiliki model pembelajaran yang menarik. Melalui kerjasama dengan Bank Indonesia, sebagian siswa diundang untuk mengikuti pembelajaran bersama di aula Bank Indonesia Jember. Pembelajaran tentang moneter oleh Bank Indonesia tentu saja memberikan pengalaman belajar yang lebih kontekstual. Selain itu, melalui kerjasama dengan Majelis ekonomi PDM Jember, sekolah juga mengundang pelaku usaha sekaligus motivator untuk memberikan pemahaman tentang entrepreneurship agar terbentuk mental sekaligus pola pikir wirausaha pada diri siswa. Sedangkan pada mata pelajaran Sosiologi, guru mengajak siswa untuk melakukan observasi lapangan pada bank sampah komunitas yang mampu mengatasi persoalan sampah non organik sekaligus memberdayakan ibu-ibu untuk mengolah limbah tersebut menjadi barang bernilai ekonomi. Melalui kegiatan ini siswa mampu memaknai bahwa melalui inovasi dan kreatifitas sebuah komunitas mampu menambah pendapatan rumah tangga sekaligus menghambat kerusakan lingkungan akibat ulah manusia. 
Pada rumpun IPA datayang diambil antara lain adalah guru Fisika, Biologi, dan Kimia. Berdasarkan pernyataan guru Fisika, salah satu cara agar ia mampu menghadirkan pembelajaran dengan pendekatan saintifik adalah memberikan tugas tematik berbasis proyek di akhir semester. Siswa diminta membuat kelompok untuk membuat alat berdasarkan materi pelajaran yang telah diberikan selama 1 semester. Karya siswa yang telah terinventarisir antara lain kompor biomasa, pompa air sederhana, alat pemotong gabus, dan masih banyak karya lainnya. Guru Biologi berkolaborasi dengan siswa ekstrakurikuler Karya Ilmiah Remaja (KIR) membuat camilan berbahan dasar buah naga dengan perhitungan yang cermat mengenai komposisi dan manfaatnya berdasarkan jurnal penelitian sebelumnya untuk diikutkan dalam sebuah kompetisi karya ilmiah pelajar. Guru pelajaran Kimia memberikan inspirasi pemanfaatan limbah ikan di tempat pelelangan ikan pantai Puger Jember agar mampu diubah menjadi pupuk cair yang bernilai ekonomi serta bermanfaat bagi pengurangan ketergantungan petani terhadap pupuk non organik. Team Karya Ilmiah Remaja dibimbing melakukan riset lapangan hingga membuat laporan berbentuk Karya Ilmiah. Kegiatan ini memberikan kesan sekaligus pengalaman yang sangat berharga bagi siswa bahwa melalui pemanfaatan laboratorium sekolah, yang didukung oleh peralatan teknologi informasi dan komunikasi, mampu menghasilkan sebuah penemuan baru dari limbah ikan yang selama ini hanya dimanfaatkan untuk industri pakan ternak.

Semangat menghasilkan karya tulis ini ternyata juga merambah di bidang lain. Proyek majalah sekolah sejak tahun 2016 telah mampu menerbitkan dua edisi majalah dan saat ini sedang menyelesaikan edisi ketiga. Hal ini merupakan langkah maju bagi team karya ilmiah SMA Muhammadiyah 3 Jember. Jika sebelumnya mereka hanya mampu membuat majalah dinding yang jarang dilirik dan dibaca oleh warga sekolah, maka dengan bantuan beberapa guru pembimbing mereka mampu menghasilkan produk majalah sekolah ber-ISSN dan mulai dapat bersaing dalam kompetisi majalah sekolah. Majalah sekolah ternyata mampu menghasilkan multiplayer effect bagi sekolah, antara lain:

a. Tumbuhnya motivasi menulis dari guru dan siswa. Hal ini secara langsung akan memberikan edukasi tentang cara menulis yang baik dan benar 
b. Media kreatifitas bagi guru dan siswa. Beraneka ragamnya tulisan yang masuk ke meja redaksi menunjukkan guru dan siswa kreatif dalam membuat artikel dari berbagai sudut pandang

c. Media literasi bagi guru dan siswa. Melalui kegiatan membaca dan menulis artikel akan menambah wawasan dan referensi sumber bacaan sehingga tidak mudah termakan berita bohong.

d. Pemetaan bakat dan minat menulis guru dan siswa. Team editing, terutama guru bahasa Indonesia, dapat memetakan tingkat kemampuan menulis guru dan siswa baik itu kategori penulisan artikel, berita, cerpen, maupun puisi melalui beragam artikel yang masuk ke meja redaksi.

e. Mampu menjaring dan mempertajam kemampuan siswa berbakat di bidang menggambar konvensional maupun yang menggunakan peralatan teknologi untuk membuat desain cover, ilustrasi, dan kartun pendek

f. Media efektif sosialisasi sekaligus promosi kegiatan sekolah kepada orang tua siswa dan calon siswa pada masa promosi sekolah.

g. Meningkatkan branding sekolah di mata masyarakat sebab prestasi yang diraih oleh para siswa SMA Muhammadiyah 3 Jember. 
Bakhtiar:kebijakan Pendidikan

Kosmopolitan Muhammadiyah Di Tengah

Tantangan Era Disrupsi

TABEL 1. Kegiatan Pengembangan Edupreneurship dan Penanaman Nilai Keislaman dalam Intrakurikuler dan Ekstrakurikuler

\begin{tabular}{|c|c|c|c|}
\hline No & $\begin{array}{l}\text { Kegiatan } \\
\text { /Pelajaran }\end{array}$ & $\begin{array}{l}\text { Kegiatan Pengembangan } \\
\text { Edupreneurship }\end{array}$ & $\begin{array}{l}\text { Nilai Keislaman dan } \\
\text { Kemanusia-an }\end{array}$ \\
\hline 1 & $\begin{array}{l}\text { Kewarga- } \\
\text { negaraan }\end{array}$ & $\begin{array}{l}\text { mengajak siswa untuk observasi ke } \\
\text { beberapa lembaga penegak hukum } \\
\text { teater }\end{array}$ & \\
\hline 2 & Ekonomi & \begin{tabular}{lrrr} 
Melalui & kerjasama & \multicolumn{2}{c}{ dengan Bank } \\
Indonesia, sebagian & siswa diundang \\
untuk mengikuti & pembelajaran \\
bersama di aula & Bank Indonesia \\
Jember & & &
\end{tabular} & $\begin{array}{l}\text { mengundang pelaku usaha } \\
\text { sekaligus motivator untuk } \\
\text { memberikan pemahaman } \\
\text { tentang entrepreneurship }\end{array}$ \\
\hline 3 & Sosiologi & $\begin{array}{l}\text { mengajak siswa untuk melakukan } \\
\text { observasi lapangan pada bank sampah } \\
\text { komunitas yang mampu mengatasi } \\
\text { persoalan sampah non organik } \\
\text { sekaligus memberdayakan ibu-ibu } \\
\text { untuk mengolah limbah tersebut } \\
\text { menjadi barang bernilai ekonomi }\end{array}$ & $\begin{array}{l}\text { inovasi dan kreatifitas } \\
\text { sebuah komunitas mampu } \\
\text { menghambat kerusakan } \\
\text { lingkungan akibat ulah } \\
\text { manusia. }\end{array}$ \\
\hline 4 & Seni Budaya & $\begin{array}{l}\text { seni budaya berkolaborasi dengan } \\
\text { ekstra teater melalui karya teater }\end{array}$ & - \\
\hline 5 & Fisika & 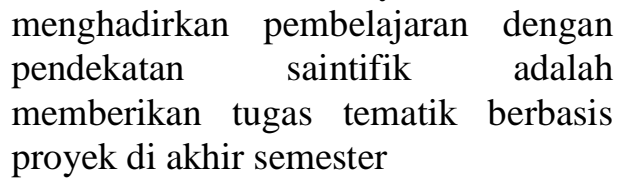 & - \\
\hline 6 & Biologi & $\begin{array}{l}\text { Guru Biologi berkolaborasi dengan } \\
\text { siswa ekstrakurikuler Karya Ilmiah } \\
\text { Remaja (KIR) membuat camilan } \\
\text { berbahan dasar buah naga dengan } \\
\text { perhitungan yang cermat mengenai } \\
\text { komposisi dan manfaatnya }\end{array}$ & - \\
\hline 7 & Kimia & $\begin{array}{l}\text { memberikan inspirasi pemanfaatan } \\
\text { limbah ikan di tempat pelelangan ikan } \\
\text { pantai Puger Jember agar mampu } \\
\text { diubah menjadi pupuk cair yang } \\
\text { bernilai ekonomi serta bermanfaat bagi } \\
\text { pengurangan ketergantungan petani } \\
\text { terhadap pupuk non organic }\end{array}$ & - \\
\hline 8 & Geografi & - & - \\
\hline 9 & Matematika & - & - \\
\hline 10 & Bahasa & - & - \\
\hline 11 & $\begin{array}{l}\text { Karya Ilmiah } \\
\text { Remaja } \\
\text { (KIR) }\end{array}$ & $\begin{array}{l}\text { Berkolaborasi dengan pelajaran kimia } \\
\text { guna memanfaatkan buah naga. }\end{array}$ & - \\
\hline 12 & Teater & $\begin{array}{l}\text { Karya teater yang berkolaborasi } \\
\text { dengan pendidikan seni budaya. }\end{array}$ & - \\
\hline 13 & $\begin{array}{l}\text { Cinematoz } \\
\text { /Videografi }\end{array}$ & Pembuatan Film - Film Pendek & \\
\hline 14 & Olahraga & - & - \\
\hline
\end{tabular}


Gambar 1. Presentase Aplikasi Nilai Edupreneurship dan Nilai Keislaman dalam Intrakurikuler dan Ekstrakurikuler

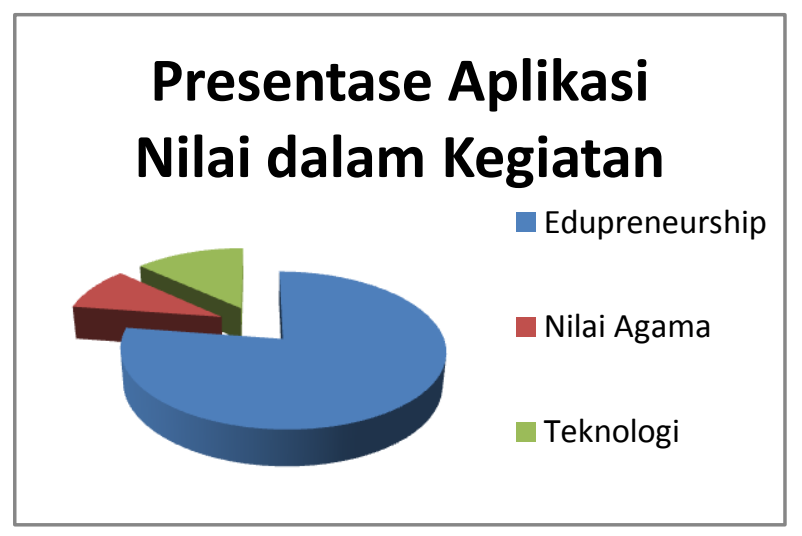

Selama dua tahun terakhir sejak lahirnya majalah sekolah, bidang kesiswaan melalui ekstrakurikuler KIR telah mampu mendorong lahirnya kartunis, penulis cerpen dan puisi yang cukup mumpuni. Secara tidak langsung majalah sekolah telah turut andil dalam lahirnya komunitas videorafi yang sejak tahun 2016 telah mampu menghasilkan karya video profil sekolah maupun film pendek serta mampu menyabet beberapa prestasi. Kebangkitan semangat dan motivasi siswa dalam berkarya tentu saja tidak dapat dilepaskan dari keteladananbeberapa guru yang telah mampu menghasilkan beberapa karya buku yang memiliki ISBN, artikel ilmiah, dan artikel opini yang dimuat di beberapa edisi Koran harian regional. Pencapaian ini menjadi bukti bahwa bibit teacherpreneurship sebagai salah satu penopang dasar penerapan edupreneurship di sekolah telah mulai tumbuh dan berkembang di SMA Muhammadiyah 3 Jember. Berikut ini adalah sebagian karya kreatif dan inovatif guru dan siswa melalui penerapan edupreneurship di sekolah periode tahun 2016 hingga tahun 2018: 


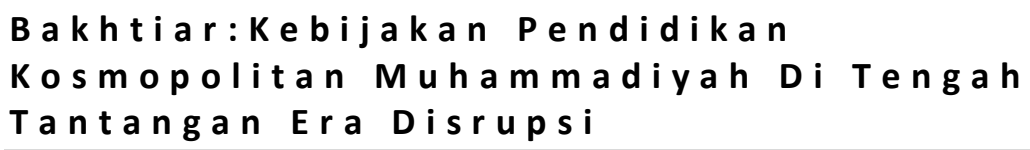

Tabel 2. Karya Guru dan Siswa SMA Muhammadiyah 3 Jember Periode 2016 - 2018

\begin{tabular}{|c|c|c|}
\hline No & Karya & Tahun \\
\hline 1 & Majalah Sekolah ZOOM IN edisi 1 & 2016 \\
\hline 2 & $\begin{array}{c}\text { Kompor Biomasa, Pompa air sederhana, alat pemotong } \\
\text { gabus, dll karya siswa proyek mata pelajaran Fisika arahan } \\
\text { bapak Syaihun Atiq }\end{array}$ & 2016 \\
\hline 3 & Video Profil SMA Muhammadiyah 3 & 2016 \\
\hline 4 & $\begin{array}{c}\text { PTK Fisika "Penerapan model pembelajaran ARCS } \\
\text { (Attention Relevant Confidence and Satisfaction) Pada Kelas } \\
\text { XII IPA oleh Syaihun Atiq }\end{array}$ & 2016 \\
\hline 5 & $\begin{array}{l}\text { "SOGOL”, Tata Artistik terbaik pada Festival Teater di } \\
\text { Kanwil DEPDIKBUD Jawa Timur oleh Suharsono }\end{array}$ & 2017 \\
\hline 6 & $\begin{array}{c}\text { Essay "Penerapan Bank Amin Disertai Pengajian Anjangsana } \\
\text { Untuk Peningkatan Kedisiplinan Siswa" }\end{array}$ & 2017 \\
\hline 7 & $\begin{array}{c}\text { LKTI siswa "Pemanfaatan Limbah Kulit Buah Naga } \\
\text { (Hylicereus costaricensis) Sebagai Permen Jelly } \\
\text { Antioksidan" }\end{array}$ & 2017 \\
\hline 8 & $\begin{array}{c}\text { "BUKAN ILUSI" pada Festival Film Pendek } \\
\text { PelajarBondowoso }\end{array}$ & 2017 \\
\hline 9 & $\begin{array}{c}\text { "BUKAN INDERA KEENAM" pada Lomba Film Pendek } \\
\text { Universitas Brawijaya }\end{array}$ & 2017 \\
\hline 10 & $\begin{array}{c}\text { "HIJRAH” juara } 3 \text { pada lomba videografi 'Kids Zaman Now' } \\
\text { UNMUH se-kabupaten Jember }\end{array}$ & 2017 \\
\hline 11 & $\begin{array}{c}\text { “SIAPA LAGI” juara } 1 \text { pada Lomba Videografi Jember IAIN } \\
\text { se-tapal kuda }\end{array}$ & 2017 \\
\hline 12 & “AXIS HITZ” pada Lomba Video Axis Hitz & 2017 \\
\hline 13 & Majalah ZOOM IN Edisi 2 & 2017 \\
\hline 14 & Video Profil SMA Muhammadiyah 3 & 2017 \\
\hline 15 & $\begin{array}{c}\text { Buku "NODA SERAGAM SEKOLAHKU" Karya Sony } \\
\text { Bakhtiar } \\
\text { ISBN 978-602-14186-4-2 }\end{array}$ & 2017 \\
\hline 16 & $\begin{array}{c}\text { Buku "DAHSYATNYA BERBAGI UNTUK NEGERI" } \\
\text { Karya Sony Bakhtiar dan Abdul Khamil } \\
\text { ISBN 978-602-5570-06-03 }\end{array}$ & 2017 \\
\hline 17 & $\begin{array}{c}\text { Artikel Opini Radar Jember "JEMBER SEBAGAI PILAR } \\
\text { KETAHANAN PANGAN NASIONAL" karya Sony } \\
\text { Bakhtiar }\end{array}$ & 2017 \\
\hline 18 & $\begin{array}{l}\text { Artikel Opini Radar Jember "MENGENAL SOSOK } \\
\text { SEORANG PAHLAWAN" karya Sony Bakhtiar }\end{array}$ & 2017 \\
\hline 19 & $\begin{array}{l}\text { Artikel Opini Radar Jember "PEMIMPIN MUDA } \\
\text { PENGAWAL KEBHINEKAAN" karya Sony Bakhtiar }\end{array}$ & 2017 \\
\hline 20 & $\begin{array}{l}\text { "INI SUARA KAMI" pada Lomba Videografi IAIN Jember } \\
\text { Se-Tapal Kuda }\end{array}$ & 2017 \\
\hline 21 & $\begin{array}{c}\text { "BUYA HAMKA" pada Festival Sinema Sekolah se-Jawa } \\
\text { Timur }\end{array}$ & 2018 \\
\hline 22 & $\begin{array}{l}\text { LKTI siswa "Mendongkrak Martabat Limbah Perikanan } \\
\text { Menjadi Pupuk Organik Cair Unggul Bagi Tanaman }\end{array}$ & 2018 \\
\hline 23 & $\begin{array}{c}\text { Budidaya" dengan pembimbing bapak Andaka Pratama } \\
\text { PTK "Penggunaan Model Scientific Method Pada } \\
\text { Pembelajaran Kewarganegaaran Pada Kelas XII IPS 3" karya } \\
\text { Diah Fatmawati }\end{array}$ & 2018 \\
\hline
\end{tabular}


Sebagai penyempurna misi pendidikan berkemajuan Muhammadiyah yang selaras dengan tujuan pendidikan nasional guna membentuk pribadi yang memiliki keimanan dan ketakwaan yang diwujudkan melalui akhlak mulia serta bermanfaat bagi masyarakat, bidang $\mathrm{Al}$ Islam dan kemuhammadiyahan menghadirkan program sholat dhuhur dan ashar berjamaah, kultum, sholat Ied, pembagian zakat, infaq, dan sedekah, penyembelihan sekaligus pembagian daging kurban bagi masyarakat sekitar sekolah dan panti asuhan, serta program Jumat berkah berupa pembagian paket sembako pada para tukang becak yang melintas di sekitar sekolah. Beberapa tahun terakhir kegiatan filantropi guru dan siswa telah menjadi agenda tahunan yang terintegrasi dengan diklat gabungan ekstrakurikuler.

\section{KESIMPULAN}

Konsep pendidikan kosmopolitan dengan semangat Pendidikan berkemajuan Muhammadiyah yang mengajarkan pendidikan berlandaskan agama dan kehidupan sosial yang sangat menghargai kecerdasan (akal/inteligensi) sebagai piranti untuk memahami pesan-pesan agama dan anatomi kehidupan sosial telah diterapkan di SMA Muhammadiyah 3 Jember melalui proses pembelajaran intrakurikuler dan ekstrakurikuler. Penerapanedupreneurship yang belum sempurna dihadirkan saat kegiatan intrakurikuler mampu dilengkapi melalui beberapa ekstrakurikuler, terutama melalui kegiatan Hizbul Wathan, Karya Ilmiah Remaja termasuk didalamnya majalah sekolah, serta komunitas Cinematoz, sehingga mampu menghadirkan pembelajaran yang kreatif, inovatif, dan menyenangkan serta mampu menghasilkan nilai tambah berupa beberapa karya dan prestasi yang membanggakan bagi siswa, guru, maupun sekolah.

Pada pelaksanaan edupreneurship di beberapa mata pelajaran serta ekstrakurikuler yang dilakukan oleh beberapa guru dan siswa yang memiliki komitmen kuat bersama untuk berkarya dan berinovasi mampu menghasilkan beragam karya yang membanggakan, maka produktivitas karya kreatif dan inovasi yang akan berhasil dihasilkan oleh guru dan siswa jika sebagian besar dari mereka memiliki kesadaran dan komitmen yang sama untuk berbuat yang terbaik di bidang tugas dan kewajibannya sudah menghasilkan karya yang terbaik.Hal ini berdampak luar biasa bagi kemajuan sekolah sekaligus peningkatan kualitas sumberdaya manusia yang adaptif terhadap beragam kondisi terutama di era disruptive innovation, atau biasa juga diistilahkan dengan disruptive technology, 


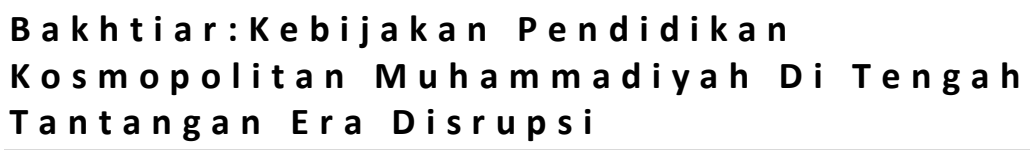

yang membutuhkan generasi muda kreatif, inovatif, serta memiliki keterampilan dan pengetahuan di bidang teknologi informasi dan komunikasi.Sesungguhnya cara terbaik dalam menghadapi disruptive innovation adalah memanfaatkan setiap peluang untuk mampu menciptakan inovasi baru lainnya.Dan jika dalam kegiatan mata pelajaran dan ekstrakurikuler yang lainnya dapat di tambahkan pelaksanaan edupreneurship untuk mengembangkan inovasi dan kreatifitas siswa dan guru. Meningkatkan keterlibatan seluruh perangkat guru dan siswa untuk menciptakan pola edupreneurship yang merata pada setiap elemen sekolah.

Seharusnya kepala sekolah dan guru harus mampu memperkuat komitmen sekaligus kesadaran tentang nilai strategis seorang guru dan lembaga pendidikan terhadap masa depan bangsa dan negara. Guru juga diharapkan tidak pernah berhenti untuk belajar dan menguasai teknologi informasi dan komunikasi serta menambah wawasan yang mampu meningkatkan kemampuan guru dari aspek pedagogik maupun profesional. Jika kepala sekolah mampu memelihara dan memperkuatatmosfir pendidikanbagi guru dan siswa yang kompatibel dengan tantangan masa depan maka sumberdaya manusia Indonesia memiliki peluang yang sangat besar untuk dapat bersaing dengan sumberdaya manusia dari negara lain.

\section{REFERENSI}

Alim, Ikhwan. 2010. "Peranan ITB Dalam Pengembangan Kewirausahaan". Menteri Koordinator Pengembangan Kemahasiswaan Kabinet KM ITB SEMINAR NASIONAL PENDIDIKAN 2017. Bandung: Indonesia.

Alwasilah, Chaedar. 2003. Chaedar Alwasilah. Bandung: Pustaka Jaya.

Anon. 2014. "Kkohl.” Retrieved (Edublogs.org).

C. Ismaniati. 2012. "Penggunaan Teknologi Informasi Dan Komunikasi Dalam Pembelajaran." Universitas Sriwijaya.

Cresswell, John W. 2002. Research Design Qualitative And Quantitative Approaches. Desain Penelitian Pendekatan Kualitatif Dan Kuantitatif. Yogyakarta: Kill Pers.

Creswell, J. .. 2014. Research Design: Pendekatan Kualitatif, Kuantitatif Dan Mixed. Terjemahan Fawaid, A. Yogyakarta: Pustaka Pelajar.

E. Mulyatiningsih, Sugiyono, and Purwanti Sutriyati. 2014. “"EDUPRENEURSHIP Sekolah Kejuruan.”" Universitas Negeri Surabaya.

Gokan, Y. 2011. "Poverty Traps, the Money Growth Rule, and the Stage of Financial Development." Journal of Economic Dynamics and Control 
35(8):1273-1287.

Karsidi, Ravik. 2017. "Budaya Lokal Dalam Liberalisasi Pendidikan ." The Journal of Society and Media 1(2): 19-34

M. Ali, S. A. Kuntoro, and Sutrisno. 2016. “'Kata Kunci :,' J. Pembang. Pendidik. Fondasi Dan Apl.,." 4(1):43-58.

Melinda, Nurlyy. 2018. "SOCIAL MEDIA ON CAMPUS: Studi Peran Media Sosial Sebagai Media Penyebaran Informasi Akademik Pada Mahasiswa Di Program Studi Ilmu Komunikasi FISIP UNSRI." The Journal of Society \& Media, 1(2):53-64.

Nuryanto, Agus. 2017. "Kritik Budaya Akademik Di Pendidikan Tinggi ." The Journal of Society and Media 1(1): 35-42

Nussbaum, Martha C. 2006. “Kant and Cosmopolitanism” Dalam Perpetual Peace. The MIT Press.

Project, Oxford. 2012. "Leading through Edupreneurship.” Oxford Community Schools.

Sukirno, Sadono. 2006. Ekonomi Pembangunan (Edisi Kedua). Jakarta: Kencana.

Warsono. 2017. "Guru: Antara Pendidik, Profesi, Dan Aktor Sosial ." The Journal of Society and Media 1(1): 1-10 